\title{
Multiplicity of Sulfate and Molybdate Transporters and Their Role in Nitrogen Fixation in Rhizobium leguminosarum bv. viciae RIv3841
}

\author{
Guojun Cheng, ${ }^{1,2}$ Ramakrishnan Karunakaran, ${ }^{2}$ Alison K. East, ${ }^{2,3}$ and Philip S. Poole ${ }^{2,3}$ \\ ${ }^{1}$ College of Life Science, South-Central University for Nationalities, Wuhan 430074, China; ${ }^{2}$ Department of Molecular \\ Microbiology, John Innes Centre, Norwich Research Park, Norwich, NR4 7UH, U.K.; and ${ }^{3}$ Department of Plant Sciences, \\ University of Oxford, South Parks Road, Oxford, OX1 3RB, U.K.
}

Submitted 22 September 2015. Accepted 27 October 2015.

\begin{abstract}
Rhizobium leguminosarum Rlv3841 contains at least three sulfate transporters, i.e., SulABCD, SulP1 and SulP2, and a single molybdate transporter, ModABC. SulABCD is a high-affinity transporter whose mutation prevented growth on a limiting sulfate concentration, while SulP1 and SulP2 appear to be lowaffinity sulfate transporters. ModABC is the sole high-affinity molybdate transport system and is essential for growth with $\mathrm{NO}_{3}{ }^{-}$ as a nitrogen source on limiting levels of molybdate $(<0.25 \mu \mathrm{M})$. However, at $2.5 \mu \mathrm{M}$ molybdate, a quadruple mutant with all four transporters inactivated, had the longest lag phase on $\mathrm{NO}_{3}{ }^{-}$, suggesting these systems all make some contribution to molybdate transport. Growth of RIv3841 on limiting levels of sulfate increased sulB, sulP1, modB, and sulP2 expression 313.3-, 114.7-, 6.2-, and 4.0-fold, respectively, while molybdate starvation increased only modB expression (three- to 7.5 -fold). When grown in highsulfate but not low-sulfate medium, pea plants inoculated with LMB695 $(\operatorname{modB})$ reduced acetylene at only $14 \%$ of the wild-type rate, and this was not further reduced in the quadruple mutant. Overall, while $\bmod B$ is crucial to nitrogen fixation at limiting molybdate levels in the presence of sulfate, there is an unidentified molybdate transporter also capable of sulfate transport.
\end{abstract}

Sulfur (S) is an essential element for living organisms and is usually available to bacteria, fungi, and plants as sulfate $\left(\mathrm{SO}_{4}{ }^{2-}\right)$ (Kertesz and Mirleau 2004). Sulfate is a strong acid that is completely ionized at physiological $\mathrm{pH}$, necessitating its uptake by active transport systems. Sulfate transport in bacteria is catalyzed by ABC-type transporters from the SulT family as well as MFS transporters from the SulP family (Kertesz 2001).

SulT is the main sulfate and thiosulfate transporter and has been studied in detail in Salmonella typhimurium and Escherichia coli. This transport system consists of a complex of five types of subunits encoded by $s b p$ (sulfate-binding protein gene), cys $P$, cys $U$, cys $W$, and cysA (Kertesz 2001; Sirko et al. 1995). Sulfate assimilation is initiated by the periplasmic SBP or thiosulfate binding protein (CysP), which interacts with the membrane permease components CysT and CysW. CysA comprises a nucleotide-binding (ATP-binding) and a regulatory domain that changes conformation upon binding of ATP

Corresponding author: P. Poole; E-mail: philip.poole@plants.ox.ac.uk

*The $\boldsymbol{e}$-Xtra logo stands for "electronic extra" and indicates that one supplementary table is published online.

Copyright $\odot 2016$ The Author(s). This is an open access article distributed under the CC BY Attribution 4.0 International license.
(Hryniewicz et al. 1990; Scheffel et al. 2005). In S. typhimurium and E. coli, SulT subunits are encoded by the cysPTWA operon, with $s b p$ located elsewhere on the genome (Kertesz 2001). Single cys $P$ and $s b p$ mutants in $E$. coli are able to utilize both sulfate and thiosulfate as a sole $\mathrm{S}$ source, demonstrating that the two proteins overlap in their solute range. By contrast, a mutant in cys $T$ was a cysteine auxotroph, as was the $c y s P$ and $s b p$ double mutant (Sirko et al. 1995). Genes encoding these components are tightly regulated at two levels by transcriptional regulators of the LysR family. However, CysB appears to play the main role in activation of genes encoding the sulfate uptake complex upon S starvation (Kredich 1996; Piłsyk and Paszewski 2009).

Many genera lack SulT but, instead, contain a sulfate permease from the SulP superfamily, consisting of hundreds of sequenced members, although few have been functionally characterized (Saier et al. 2006). They are found in prokaryotes, including Yersinia enterolitica, Bacillus subtilis (two copies), and Pseudomonas aeruginosa, and are present in a number of incomplete genome sequences (Kertesz 2001; Piłsyk and Paszewski 2009). Several of the latter contain two or more SulP-type permeases (Kertesz 2001). P. aeruginosa contains both SulT and SulP transporters, with SulT expressed under low-sulfate conditions (Quadroni et al. 1999). Due to their low substrate specificity, sulfate permeases may also transport other tetra-oxyanions like molybdate (Kertesz 2001).

Molybdenum (Mo), in its readily soluble form of molybdate $\left(\mathrm{MoO}_{4}{ }^{2-}\right)$, is essential for bacterial growth (Smith et al. 1997). It is incorporated into apoenzymes such as Moco, a Mo cofactor comprising a mononuclear Mo atom coordinated to the $\mathrm{S}$ atoms of a pterin called molybdopterin (Hille 2002). In E. coli, highaffinity molybdate transport is mediated by an ABC-type ModABC transport system. ModA is a periplasmic molybdatebinding protein, ModB is a transmembrane permease, while ModC is an ATPase that energizes transport on the cytoplasmic side of the membrane (Grunden and Shanmugam 1997). Similar systems for molybdate transport have been characterized in Rhodobacter capsulatus, Azotobacter vinelandii, Anabaena variabilis, and Bradyrhizobium japonicum (Delgado et al. 2006; Zahalak et al. 2004). The modABC operon of E. coli is negatively regulated by molybdate via a regulatory protein, ModE (Anderson et al. 2000). In strains deficient in molybdate transport or mutated in $\bmod E$, there is little transcription of modABC (Anderson et al. 2000). However E. coli, as well as using ModABC, transports molybdate via SulT (Kertesz 2001; Sirko et al. 1990).

Rhizobium leguminosarum bv. viciae is a gram-negative soil bacterium that induces formation of nitrogen $(\mathrm{N})$-fixing nodules 
with several hosts, including pea (Pisum sativum), lentil (Lens culinaris), and Vicia spp. Within nodules, rhizobia differentiate into bacteroids that reduce atmospheric di-nitrogen $\left(\mathrm{N}_{2}\right)$ to ammonia through the Mo-iron nitrogenase complex, thus providing the plant with a source of fixed N (Terpolilli et al. 2012). In turn, the plant must provide carbon, phosphorous, N, S, and Mo. Considering the special function played by the nitrogenase complex in Rhizobium species, uptake of molybdate and sulfate are particularly important and their similar structural characteristics mean they can be transported into the cell by the same type of carriers. Moreover, repression of sulfate transport may result in inhibition of molybdate uptake by bacteroids, but the mechanism is unknown (Delgado et al. 2006). Despite the importance of $\mathrm{S}$ and Mo in $\mathrm{N}$ fixation, there has been very little work on the mechanisms involved in their uptake in rhizobia. We investigated the roles of $R$. leguminosarum sulfate and molybdate transporters in free-living bacteria and during N-fixing symbiosis on Pisum sativum by analyzing the phenotypes of mutant strains, each lacking one to four of the putative sulfate and molybdate transporter systems identified in the Rlv3841 genome.

\section{RESULTS}

\section{Molybdate and sulfate transport systems.}

Bioinformatic analysis of Rlv3841 revealed the presence of a single putative molybdate transporter (ModABC) and three putative sulfate transporters (Fig. 1). ModABC is an $A B C$ transporter composed of a SBP encoded by $\operatorname{modA}$ (RL4685), a permease encoded by $\operatorname{modB}$ (RL4686), and an ATP-binding protein encoded by modC (RL4687).

One of the three putative sulfate transporters in Rlv3841 is an ABC transporter of the SulT family. Located on plasmid pRL11 (Young et al. 2006), sulA (pRL110374) encodes a SBP, sulB (pRL110373) and sulC (pRL110372) encode permease components, and sulD (pRL110371) encodes an ATP-binding protein (Fig. 1). The remaining sulfate transporters are two chromosomal
SulP-type permeases, SulP1 (RL2866) and SulP2 (RL2944). To characterize the role of these transporters and interaction between sulfate and molybdate transport, single and multiple mutants were made in all these transporters by combining the mutated Mod and Sul transport systems (each marked with a different antibiotic resistance gene) by means of mutagenesis and transduction between Rlv3841 and mutant strains (Table 1).

\section{Growth of sul mutants on sulfate.}

To investigate the role of each of the three Sul transport systems identified bioinformatically, growth of strains mutated in each system was compared with that of wild-type Rlv3841. A mutant in the Sul system, by inactivation of either sulA (pRL110374) or sulB (pRL110373) (Fig. 1), gave strains LMB595 and LMB584, respectively (Table 1), which were unable to grow in liquid acid minimal salt (AMS) medium supplemented with $20 \mu \mathrm{M}$ sodium sulfate as the sole $S$ source (Figs. 2 and $3 \mathrm{~A}$ ). Ability to grow in this media was restored to these Sul mutants either by complementation with pLMB731 (sulABCD cloned in a multicopy plasmid), giving strains LMB631 and LMB633 (Fig. 2), or by addition of $2 \mathrm{mM}$ sodium sulfate to the growth medium (Fig. 3B). Mutants in either sulP1 or sulP2 (strains LMB700 and LMB694) grew at the same rate as wild-type Rlv3841 with $20 \mu \mathrm{M}$ sulfate as sole $\mathrm{S}$ source (Fig. 3A). This shows that SulABCD is the main highaffinity sulfate transport system in Rlv3841.

Single $s u l B$, sulP1, and sulP2 mutants grew at the same rate as wild type on $2 \mathrm{mM}$ sulfate (Fig. 3B). However, the triple mutant LMB708 (sulB sulP1 sulP2) had slightly reduced growth compared with the wild-type strain (Fig. 3B). This is consistent with SulP1 and SulP2 being transporters with a lower affinity for sulfate but suggests there are one or more additional unidentified low-affinity $\mathrm{S}$ transporters in Rlv3841, as this triple mutant is still able to grow.

\section{Growth of sul and mod mutants on molybdate.}

Comparison of growth of transport-system mutants was used to discover their role in molybdate transport in Rlv3841. In
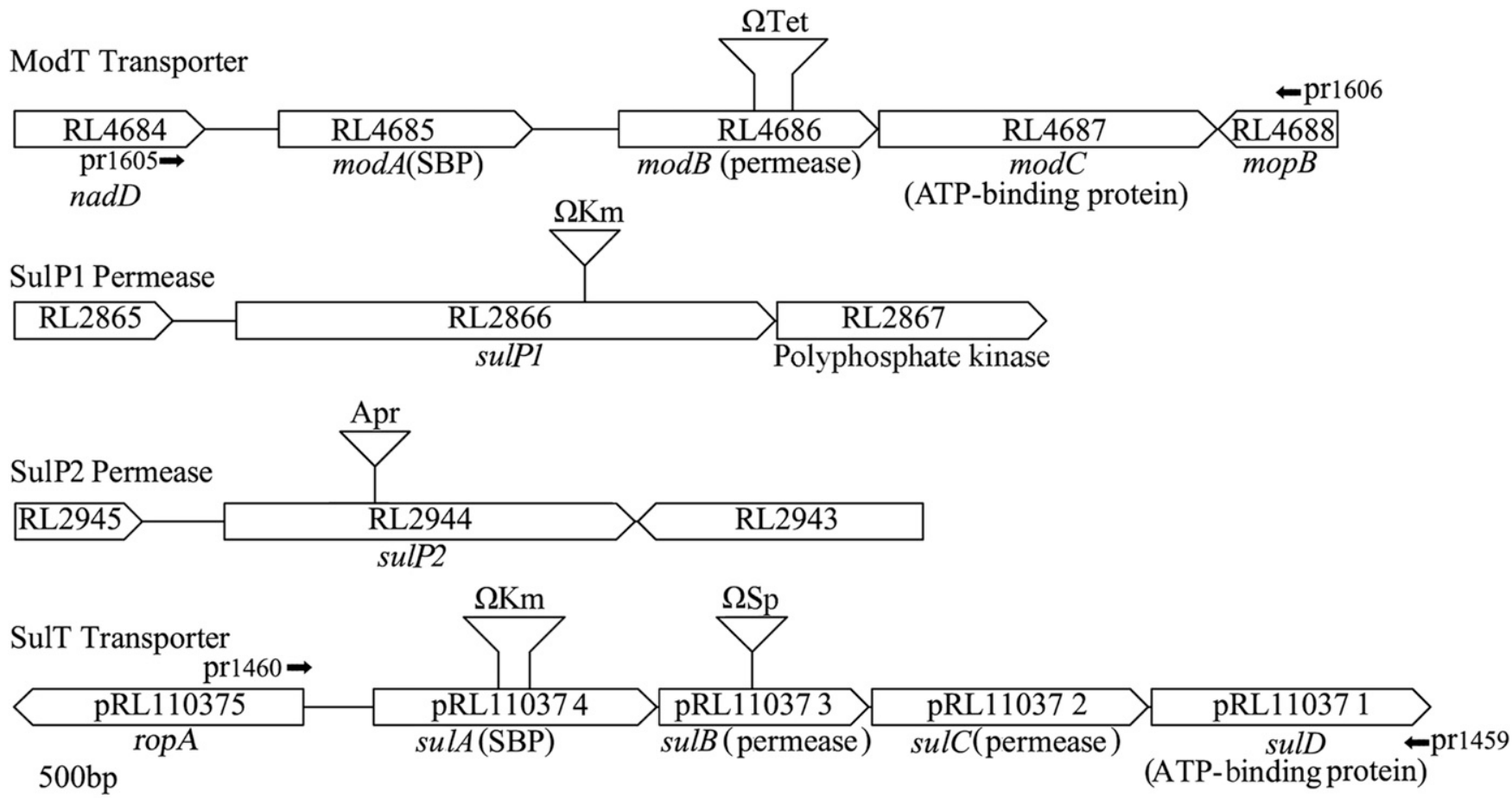

Fig. 1. Organization of genes encoding a molybdate transporters (ModABC) and sulfate (Sul) transporters in Rlv3841. Arrows indicate location and orientation of open reading frames. The solid black arrows indicate the positions of primers used to generate the polymerase chain reaction products cloned to complement mutations in modABC (pr1605/pr1606 product cloned in pLMB801) and sulABCD (pr1459/pr1460 product cloned in pLMB731). Positions of insertion of genes encoding resistance to antibiotics (Apr $=$ apramycin, $\Omega \mathrm{Km}=$ kanamycin, $\Omega \mathrm{Sp}=$ spectinomycin, $\Omega$ Tet $=$ tetracycline) into $\bmod$ and sul genes to obtain mutants are shown. 
contrast to Rlv3841, strain LMB695 $(\operatorname{modB})$ failed to grow aerobically in AMS glucose nitrate $\left(\mathrm{Glc} / \mathrm{NO}_{3}{ }^{-}\right)$media, nitrate acting as the sole $\mathrm{N}$ source, without the addition of molybdate (Fig. 4A). This media was used because nitrate reductase, required for growth of rhizobia on nitrate as the sole $\mathrm{N}$ source, is a molybdoenzyme (Ferroni et al. 2011). Therefore, growth of rhizobia in this medium is dependent on sufficient Mo being available to the bacterial cell. By complementing LMB695 ( $\operatorname{modB}$ ) with plasmid pLMB801 (containing the whole of $\bmod A B C$ ), strain LMB741 (LMB695[pLMB801]) was able to grow in AMS Glc/ $\mathrm{NO}_{3}{ }^{-}$medium, using nitrate as the sole $\mathrm{N}$ source without added molybdate (Fig. 4A). Addition of molybdate to AMS Glc/ $/ \mathrm{NO}_{3}{ }^{-}$medium at concentrations $\geq 0.25 \mu \mathrm{M}$ supported slow growth of LMB695 $(\operatorname{modB})$ with a very long lag phase
(Fig. 4B, C, and D). Moreover, at a molybdate concentration of $2.5 \mu \mathrm{M}$, the quadruple mutant in which all four Mod and Sul transport systems are inactivated (Table 1, LMB709) had a longer lag phase and slightly reduced growth rate compared with the other mutant strains (Fig. 4D), indicating a role for Sul transporters in molybdate uptake.

To further investigate whether sulfate can block molybdate transport, Rlv3841 and LMB695 $(\operatorname{modB})$ were grown in S- and Mo-free AMS Glc/ $\mathrm{NO}_{3}{ }^{-}$medium supplemented with $0.5 \mu \mathrm{M}$ sodium molybdate and sodium sulfate at either $50 \mu \mathrm{M}$ (low) or $2 \mathrm{mM}$ (high concentration) (Fig. 5). A concentration of $0.5 \mu \mathrm{M}$ sodium molybdate was chosen because it is sufficiently high to enable growth on $\mathrm{NO}_{3}{ }^{-}$as the sole $\mathrm{N}$ source when the highaffinity ModABC is inactivated in LMB695 $(\operatorname{modB})$. There were

Table 1. Strains, vectors, and plasmids

\begin{tabular}{|c|c|c|c|c|c|}
\hline Names & Description $^{z}$ & Reference & Names & Description $^{z}$ & Reference \\
\hline \multirow[t]{2}{*}{$\begin{array}{l}\text { Strains } \\
\text { Rlv3841 }\end{array}$} & Rhizobium leguminosarum & Johnston and & pRK2013 & Helper plasmid for mobilization; Kan $/ \mathrm{Neo}^{\mathrm{r}}$ & $\begin{array}{l}\text { Figurski and } \\
\text { Helinski } 1979\end{array}$ \\
\hline & 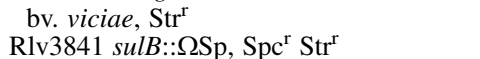 & $\begin{array}{l}\text { Beringer } 1975 \\
\text { This study }\end{array}$ & pRK415-1 & IncP broad host-range cloning vector, $\mathrm{Tet}^{\mathrm{r}}$ & Keen et al. 1988 \\
\hline LMB595 & $\operatorname{Rlv3841\Delta sulA::\Omega Km,\text {Kan/Neo}}{ }^{\mathrm{r}} \mathrm{Str}^{\mathrm{r}}$ & This study & \multirow{2}{*}{$\begin{array}{l}\text { Plasmids } \\
\text { pLMB670 }\end{array}$} & & \\
\hline LMB631 & LMB584[pLMB731], Spc ${ }^{\mathrm{r}} \mathrm{Str}^{\mathrm{r}} \mathrm{Tet}^{\mathrm{r}}$ & This study & & pr1382/pr1383 PCR product of sulA & This study \\
\hline LMB633 & $\begin{array}{l}\text { LMB595[pLMB731], Kan/Neo }{ }^{\mathrm{r}} \\
\text { Str }^{\mathrm{r}} \mathrm{Tet}^{\mathrm{r}}\end{array}$ & This study & \multirow{2}{*}{ pLMB671 } & $\begin{array}{l}\text { cloned in pJET1.2/blunt; } \text { Amp }^{r} \\
\text { pr1388/pr1389 PCR product of } s u l B\end{array}$ & \multirow{2}{*}{ This study } \\
\hline LMB694 & Rlv3841 sulP2::Apr, Apr $^{\mathrm{r}} \mathrm{Str}^{\mathrm{r}}$ & This study & & cloned in pJET1.2; Amp $^{r}$ & \\
\hline LMB695 & Rlv3841 $\bmod B:: \Omega T e t, \operatorname{Str}^{r} \operatorname{Tet}^{r}$ & This study & pLMB674 & $\Omega S p$ cassette cloned into unique & \multirow[t]{2}{*}{ This study } \\
\hline LMB696 & 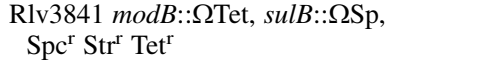 & This study & \multirow{2}{*}{ pLMB675 } & $\begin{array}{l}\text { FspAI site in pLMB671; } \mathrm{Amp}^{\mathrm{r}} \mathrm{Spc}^{\mathrm{r}} \\
\text { BglII fragment from pLMB674 }\end{array}$ & \\
\hline LMB697 & $\begin{array}{l}\text { Rlv3841 modB::STet, sulB::SSp, sulP2:: } \\
\text { Apr, } \operatorname{Apr}^{r} \operatorname{Spc}^{\mathrm{r}} \operatorname{Str}^{\mathrm{r}} \operatorname{Tet}^{\mathrm{r}}\end{array}$ & This study & & $\begin{array}{l}\text { cloned into BamHI site of } \\
\text { pJQ200SK; } \mathrm{Gm}^{\mathrm{r}} \mathrm{Spc}^{\mathrm{r}}\end{array}$ & This study \\
\hline LMB698 & $\begin{array}{l}\text { Rlv3841 sulB::SSp, sulP2::Apr, Apr }{ }^{\mathrm{r}} \\
\mathrm{Spc}^{\mathrm{r}} \mathrm{Str}^{\mathrm{r}}\end{array}$ & This study & \multirow[t]{2}{*}{ pLMB680 } & $\begin{array}{l}\text { Inverse PCR with pr1384/pr1385 } \\
\text { of pLMB670, digested with }\end{array}$ & \multirow[t]{2}{*}{ This study } \\
\hline LMB699 & 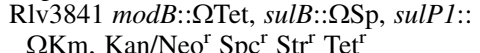 & This study & & EcoRI and religated; $\mathrm{Amp}^{\mathrm{r}}$ & \\
\hline LMB700 & Rlv3841 sulP1::SKm, Kan/Neo ${ }^{\mathrm{r}} \mathrm{Str}^{\mathrm{r}}$ & This study & pLMB681 & $\begin{array}{l}\Omega K m \text { cassette cloned into EcoRI site } \\
\text { in pLMB680; } \mathrm{Amp}^{\mathrm{r}} \mathrm{Kan} / \mathrm{Neo}^{\mathrm{r}}\end{array}$ & This study \\
\hline LMB701 & $\begin{array}{l}\mathrm{Rlv3841} \text { sulP1::SKm, sulP2::Apr, } \\
\text { Apr }^{\mathrm{r}} \mathrm{Kan} / \mathrm{Neo}^{\mathrm{r}} \mathrm{Str}^{\mathrm{r}}\end{array}$ & This study & pLMB682 & $\begin{array}{l}\text { XhoI/XbaI fragment from pLMB681 } \\
\text { cloned in pJQ200SK; } \mathrm{Gm}^{\mathrm{r}} \mathrm{Kan} / \mathrm{Neo}^{\mathrm{r}}\end{array}$ & This study \\
\hline LMB702 & $\begin{array}{l}\text { Rlv3841 modB:: } \Omega \text { Tet, sulP2::Apr, } \\
\operatorname{Apr}^{r} \operatorname{Str}^{r} \operatorname{Tet}^{r}\end{array}$ & This study & \multirow[t]{2}{*}{ pLMB731 } & $\begin{array}{l}\text { pr1459/pr1460 PCR product } \\
\text { (containing sulABCD) cloned }\end{array}$ & \multirow[t]{2}{*}{ This study } \\
\hline LMB705 & $\begin{array}{l}\text { Rlv3841 sulP1::SKm, sulB::SSp, } \\
\text { Kan/Neo }{ }^{r} \operatorname{Spc}^{r} \operatorname{Str}^{r}\end{array}$ & This study & & in pRK415-1 XbaI site; Tet $^{\mathrm{r}}$ & \\
\hline LMB706 & $\begin{array}{l}\mathrm{R} 1 v 3841 \operatorname{modB}:: \Omega \mathrm{Tet}, \operatorname{sulP} 1:: \Omega \mathrm{Km}, \\
\mathrm{Str}^{\mathrm{r}} \mathrm{Tet}^{\mathrm{r}} \mathrm{Kan} / \mathrm{Neo}^{\mathrm{r}}\end{array}$ & This study & pLMB734 & $\begin{array}{l}\text { pri463/pri464 } \\
\text { containing sulP1 cloned in } \\
\text { pJET1.2; } \text { Amp }^{\mathrm{r}}\end{array}$ & This study \\
\hline LMB707 & $\begin{array}{l}\text { Rlv3841 modB::STet, sulP1::SKm, } \\
\text { sulP2::Apr, Apr }{ }^{\mathrm{r}} \mathrm{Kan} / \mathrm{Neo}^{\mathrm{r}} \mathrm{Str}^{\mathrm{r}} \mathrm{Tet}^{\mathrm{r}}\end{array}$ & This study & \multirow[t]{2}{*}{ pLMB751 } & pr1467/pr1468 PCR product & \multirow[t]{2}{*}{ This study } \\
\hline LMB708 & 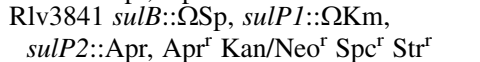 & This study & & pJET1.2; Amp $^{\mathrm{r}}$ & \\
\hline LMB709 & 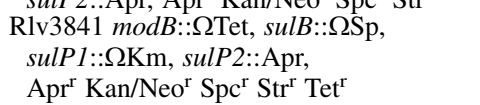 & This study & pLMB752 & 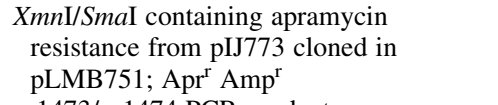 & This study \\
\hline LMB741 & LMB695[pLMB801], Spc $^{r}$ Str $^{r}$ Tet $^{r}$ & This study & pLMB754 & $\begin{array}{l}\text { pr1473/pr1474 PCR product } \\
\text { containing } \operatorname{modB} \text { into pJET1.2; } \text { Amp }^{\mathrm{r}}\end{array}$ & This study \\
\hline \multirow{3}{*}{$\begin{array}{l}\text { Vectors } \\
\text { pIJ773 } \\
\text { pJET1.2 }\end{array}$} & & & pLMB755 & $\Omega$ Tet cassette cloned into EcoRI & \multirow[t]{2}{*}{ This study } \\
\hline & aac(3)IV (AprR) oriT, Apr ${ }^{r}$ & Gust et al. 2003 & \multirow[b]{2}{*}{ pLMB756 } & site of pLMB754; $\mathrm{Amp}^{\mathrm{r}} \mathrm{Tet}^{\mathrm{r}}$ & \\
\hline & $\begin{array}{l}\text { Vector for cloning polymerase chain } \\
\text { reaction }(\mathrm{PCR}) \text { products, } \mathrm{Amp}^{\mathrm{r}}\end{array}$ & $\begin{array}{l}\text { Thermo Fisher } \\
\text { Inc. }\end{array}$ & & $\begin{array}{l}\text { BglII fragment from pLMB755 } \\
\text { cloned into BamHI site of }\end{array}$ & \multirow[t]{2}{*}{ This study } \\
\hline $\mathrm{pJP} 2 \mathrm{Spc}$ & Stable broad host-range cloning & P. Poole, & \multirow{2}{*}{ pLMB778 } & $\begin{array}{l}\text { pJQ200SK; } \mathrm{Gm}^{\mathrm{r}} \mathrm{Tet}^{\mathrm{r}} \\
\text { NotI fragment of pLMB752 }\end{array}$ & \\
\hline pJQ200SK & $\begin{array}{l}\text { vector, } \mathrm{Spc}^{1} \\
\text { pACYC-derivative, P15A origin of } \\
\text { replication, } \mathrm{Gm}^{\mathrm{r}}\end{array}$ & $\begin{array}{l}\text { unpublished } \\
\text { Quandt and } \\
\text { Hynes } 1993\end{array}$ & & $\begin{array}{l}\text { cloned into NotI-digested } \\
\text { pJQ200Sp, } \text { Apr }^{r} \mathrm{Spc}^{\mathrm{r}}\end{array}$ & This study \\
\hline pJQ200Sp & $\begin{array}{l}\text { pJQ200SK-derivative, P15A } \\
\text { origin of replication, } \mathrm{Gm}^{\mathrm{r}} \mathrm{Spc}^{\mathrm{r}}\end{array}$ & $\begin{array}{l}\text { P. Poole, } \\
\text { unpublished }\end{array}$ & pLMB784 & $\begin{array}{l}\text { EcoRI end-filled } \Omega \text { Km cassette } \\
\text { cloned into pLMB734 Sma I site; }\end{array}$ & This study \\
\hline $\mathrm{pHP} 45 \Omega \mathrm{Sp}$ & pBR322-derivative carrying & Fellay et al. & \multirow{3}{*}{ pLMB785 } & $\mathrm{Amp}^{\mathrm{r}} \mathrm{Kan} / \mathrm{Neo}^{\mathrm{r}}$ & \\
\hline & $\Omega \mathrm{Sp}, \mathrm{pHP} 45$ replicon, $\mathrm{Spc}^{\mathrm{r}}$ & 1987 & & XhoI fragment from pLMB784 & This study \\
\hline $\mathrm{pHP} 45 \Omega \mathrm{Km}$ & $\begin{array}{l}\text { pBR322-derivative carrying } \\
\Omega K m, \text { pHP45 replicon, }\end{array}$ & $\begin{array}{l}\text { Fellay et al. } \\
1987\end{array}$ & & $\begin{array}{l}\text { cloned into XhoI site of pJQ200SK; } \\
\mathrm{Gm}^{\mathrm{r}} \mathrm{Kan} / \mathrm{Neo}^{\mathrm{r}}\end{array}$ & \\
\hline & $\mathrm{Kan} / \mathrm{Neo}^{\mathrm{r}}$ & & pLMB801 & pr1605/pr1606 PCR product & This study \\
\hline $\mathrm{pHP} 45 \Omega$ Tet & $\begin{array}{l}\text { pBR322-derivative carrying } \\
\text { } 2 \text { Tet, pHP45 replicon, Tet }{ }^{r}\end{array}$ & $\begin{array}{l}\text { Fellay et al. } \\
1987\end{array}$ & & $\begin{array}{l}\text { (containing the modABC operon) } \\
\text { cloned in } \mathrm{pJP} 2 \mathrm{Spc} X b a \mathrm{I} / K p n \mathrm{I} ; \mathrm{Spc}^{\mathrm{r}}\end{array}$ & \\
\hline
\end{tabular}

\footnotetext{
${ }^{\mathrm{z}}$ Str, Spc, Kan, Neo, Tet, Apr, Amp, and Gm = streptomycin, spectinomycin, kanamycin, neomycin, tetracycline, apramycin, ampicillin, and gentamicin, respectively; ${ }^{\mathrm{r}}$ indicates resistance.
} 
no differences observed between LMB695 $(\operatorname{modB})$ and Rlv3841 when grown in medium supplemented with the low concentration of $50 \mu \mathrm{M}$ sulfate. This confirms that, even with ModABC inactivated, $0.5 \mu \mathrm{M}$ molybdate is sufficient to allow growth on $\mathrm{NO}_{3}{ }^{-}$. However, growth of LMB695 $(\operatorname{modB})$ showed a long delay in the presence of $2 \mathrm{mM}$ sulfate (Fig. 5). This is consistent with the sulfate transporters also transporting molybdate.

\section{Transcriptional analysis of sulfate and}

\section{molybdate transport genes.}

Studies on regulation of genes coding for the sulfate and molybdate transport systems were carried out using quantitative reverse transcription-polymerase chain reaction (qRT-PCR) to quantify the levels of mRNA for specific genes under different conditions. Wild-type Rlv3841 was grown overnight in AMS Glc/ $\mathrm{NH}_{4}{ }^{+}$with $1 \mu \mathrm{M}$ sodium molybdate, supplemented with sodium sulfate at either $100 \mu \mathrm{M}$ or $2 \mathrm{mM}$. Growth in the lower concentration of sulfate increased $\operatorname{sulB}, \operatorname{sulP} 1, \operatorname{modB}$, and $s u l P 2$ expression $313.3 \pm 7.2-, 1,14.7 \pm 69.8-, 6.2 \pm 2.8-$, and $4.0 \pm$ 2.3 -fold, respectively. Thus these molybdate and sulfate transporters are negatively regulated by sulfate. The high-affinity sulfate transporter SulABCD (shown by expression of $s u l B$ ) and the low-affinity SulP1 system were particularly highly induced when the level of sulfate was low. Similar regulation by sulfate concentration occurs in E. coli and P. aeruginosa (Hummerjohann et al. 1998; Tralau et al. 2007; van der Ploeg et al. 1996).

Further qRT-PCR was performed to examine levels of gene expression in LMB584 (sulB), LMB694 (sulP2), LMB700 (sulP1), and LMB701 (sulP1 sulP2) compared with Rlv3841, grown overnight in AMS Glc/ $\mathrm{NH}_{4}{ }^{+}$with $2 \mathrm{mM}$ sulfate (Table 2). Expression of sulP1 and sulP2 in LMB584 (sulB) were increased 4.8- and 8.7-fold compared with levels in Rlv3841 (Table 2). However, as there was no significant difference in expression of either sulP2 in LMB700 (sulP1) or of sulP1 in LMB694 (sulP2) compared with Rlv3841 (Table 2), it suggests that SulABCD may be involved in monitoring sulfate levels in the cell. Nevertheless, in the double mutant LMB701 ( $s u l P 1$ sulP2), the relative expression of $s u l B$, part of Sul, decreased 3.6-fold, indicating that SulABCD is negatively regulated by deletion of both sulP1 and sulP2 genes (Table 2). This suggests a complex interregulation of the sulfur transport systems. However, in each of these mutants, $\bmod B$ expression showed no significant up- or downregulation, indicating that these mutations in Sul transport systems do not affect $\operatorname{modB}$ transcription.

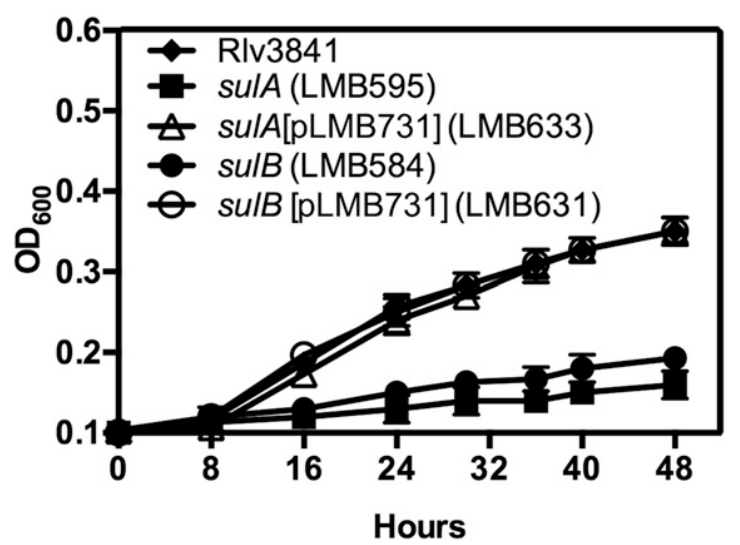

Fig. 2. Growth of Rlv3841, sulfate ( $s u l$ ) mutants, and complemented strains in $20 \mu \mathrm{M} \mathrm{Na} \mathrm{SO}_{4}$ as sole sulfate source added to $\mathrm{S}$ - and molybdenum (Mo)free acid minimal salt $\mathrm{Glc} / \mathrm{NH}_{4}{ }^{+}$with $1 \mu \mathrm{M} \mathrm{Na} 2 \mathrm{MoO}_{4}$. Wild-type Rlv3841 was compared with mutants $\Delta$ sulA (LMB595) and sulB (LMB584) and complemented mutants $\Delta$ sulA[pLMB731] (LMB633) and sulB[pLMB731] (LMB631). Data are from three biological samples \pm standard deviation.
To analyze gene expression levels under different molybdate concentrations, analysis by qRT-PCR was performed on RNA from wild-type Rlv3841 grown in AMS Glc/ $\mathrm{NO}_{3}{ }^{-}$with $2 \mathrm{mM}$ sodium sulfate, in the presence or absence of $10 \mu \mathrm{M}$ sodium molybdate. With no added molybdate, $\bmod B$ expression in early $\log$ phase and late log phase increased 3.0- and 7.5-fold, respectively (Table 3 ), suggesting $\bmod B$ is negatively regulated by molybdate. Expression of $s u l B$, sulP1, and $s u l P 2$ were not significantly altered (Table 3), indicating that these sulfate transporter systems are not regulated by molybdate.

\section{Role of Sul and Mod transporters in $\mathbf{N}$ fixation.}

In order to assess N-fixing capacity of Mod and Sul transport system mutants, Pisum sativum seedlings were inoculated with $R$. leguminosarum strains and, after 3 to 4 weeks, acetylene reduction activity was measured (Table 4$)$. When pea plants were grown without addition of Mo and S in the plant-growth

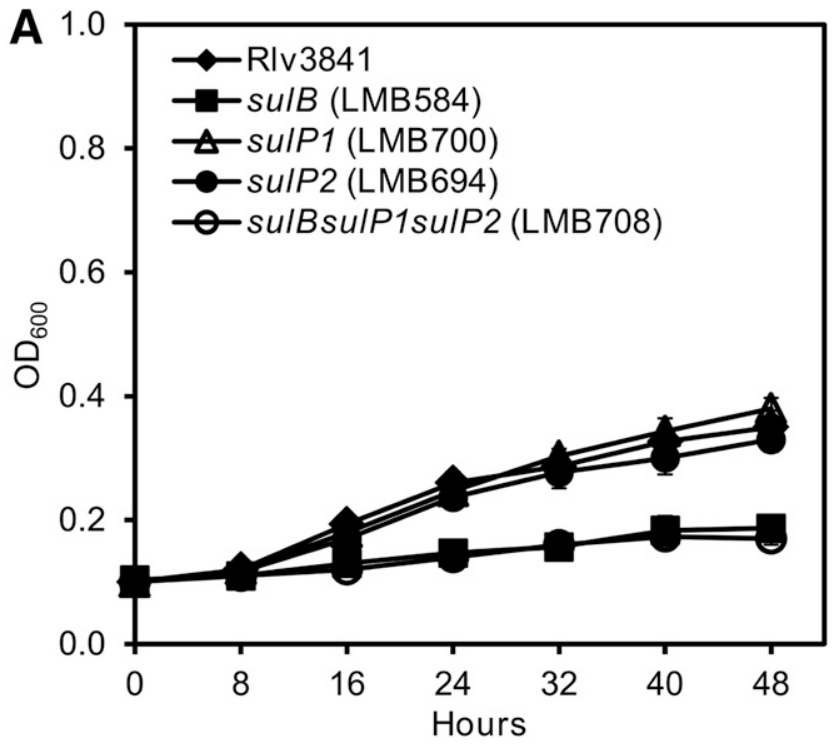

B

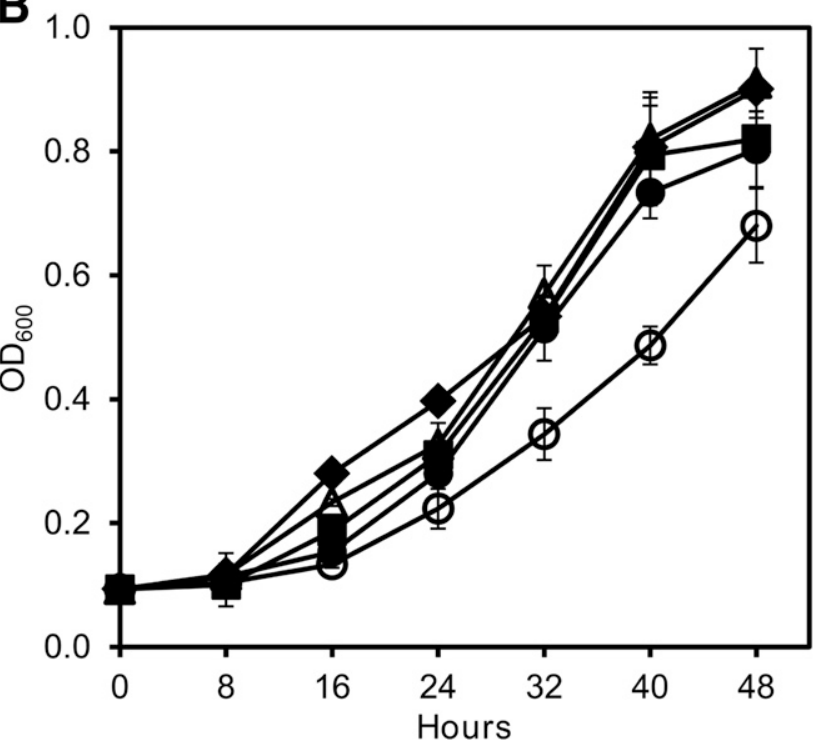

Fig. 3. Growth of Rlv3841 and Sul mutants in $\mathbf{A}, 20 \mu \mathrm{M} \mathrm{Na} \mathrm{NO}_{4}$ (low sulfate) and $\mathbf{B}, 2 \mathrm{mM} \mathrm{Na} \mathrm{SO}_{4}$ (high sulfate) media. Sulfate was added to sulfate- and molybdenum-free acid minimal salt $\mathrm{Glc} / \mathrm{NH}_{4}{ }^{+}$supplemented with $1 \mu \mathrm{M} \mathrm{Na}_{2} \mathrm{MoO}_{4}$. Wild-type Rlv3841 was compared with mutants $s u l B$ (LMB584), sulP1 (LMB700), sulP2 (LMB694), and sulB sulP1 sulP2 (LMB708). Data are from three biological samples \pm standard error of the mean. 
media, acetylene reduction activity was not significantly different in any of the mutant strains from that of Rlv3841 (Table 4). Plants were not discernably different in green color and nodules appeared pink and of similar size in all cases (data not shown). Thus, in the absence of added sulfate and molybdate even the quadruple mutant (LMB709) with all four transporter systems inactivated was not affected in its ability to fix $\mathrm{N}$, as measured by acetylene reduction. These results suggest there must be one or more other systems able to transport trace levels of either sulfate, molybdate, or both in Rlv3841 bacteroids, enabling reduction of acetylene at wild-type levels in pea nodules.

Acetylene reduction activity of plants infected with the mutants was assessed with pea plants grown in the presence of $10 \mathrm{mM}$ sodium sulfate but with no added molybdate (Table 4). The logic was that sulfate at $10 \mathrm{mM}$ would block access of molybdate to sulfate transporters, forcing uptake of molybdate to be by systems specific for this ion. Acetylene reduction by plants inoculated with the single $\operatorname{modB}$ mutant (LMB695) was only $14.4 \%$ of that of pea plants inoculated with wild-type Rlv3841, while a triple sul mutant (LMB708) was not affected in acetylene reduction (Table 4), indicating the decrease is due to mutation of $\bmod B$ alone. There were also many more small pale nodules compared with the wild type in the mod mutant (data not shown). The Mo-dependent phenotypes of the modB mutant LMB695 was only apparent in media with a high sulfate concentration. The addition of $1 \mu \mathrm{M}$ sodium molybdate to pea plants was sufficient to restore acetylene reduction in LMB695 to the wild-type level, even in the presence of $10 \mathrm{mM}$ sodium sulfate (Table 4). Paradoxically, when $\operatorname{modB}$ was combined with the three combinations of double sul mutations, there was no decrease in the rate of acetylene reduction. However, when all three characterized sul mutations were combined with $\operatorname{modB}$ in a quadruple mutant (LMB709), the rate of acetylene reduction was again reduced to $17.3 \%$ of wild type. Thus, a strain mutated in $\operatorname{modB}$ alone (LMB695) or one mutated in $\operatorname{modB}$ combined with all three characterized sulB, sulP1, sulP2 (LMB709) systems had reduced acetylene reduction but not strains with $\bmod B$ mutated in combination with partial knockouts in $S$ transport. Since this was unexpected, the experiment was repeated with a similar result (Table 4, final column). This is a complex phenotype that suggests mutating one or more Sul transporters changes either the expression, activity, or both of the remaining Sul transporters, enabling cells to scavenge enough Mo from the medium, even in the absence of ModB. This complex regulatory effect is only overcome once all three characterized Sul transporters are mutated. Presumably because the single $\bmod B$ mutation has no effect on the $\mathrm{S}$ transport systems, this gives a simple fix reduced phenotype.

Overall, these data reveal the presence of at least one unidentified molybdate transporter, which must also be capable of

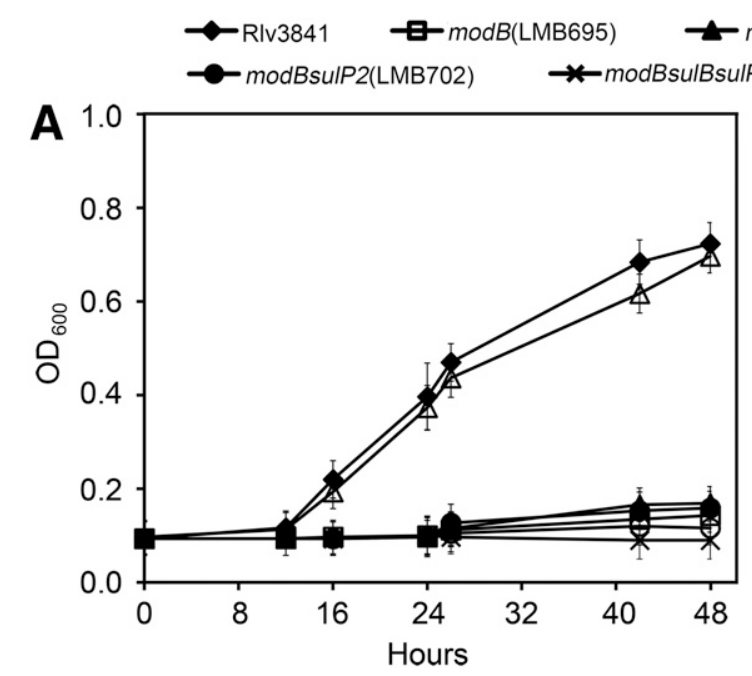

$\operatorname{modBsulB}(\mathrm{LMB} 584)$

- $\operatorname{codBsulP1}$ (LMB705) $\triangle \operatorname{modB[pLMB801]}(\mathrm{LMB} 741)$
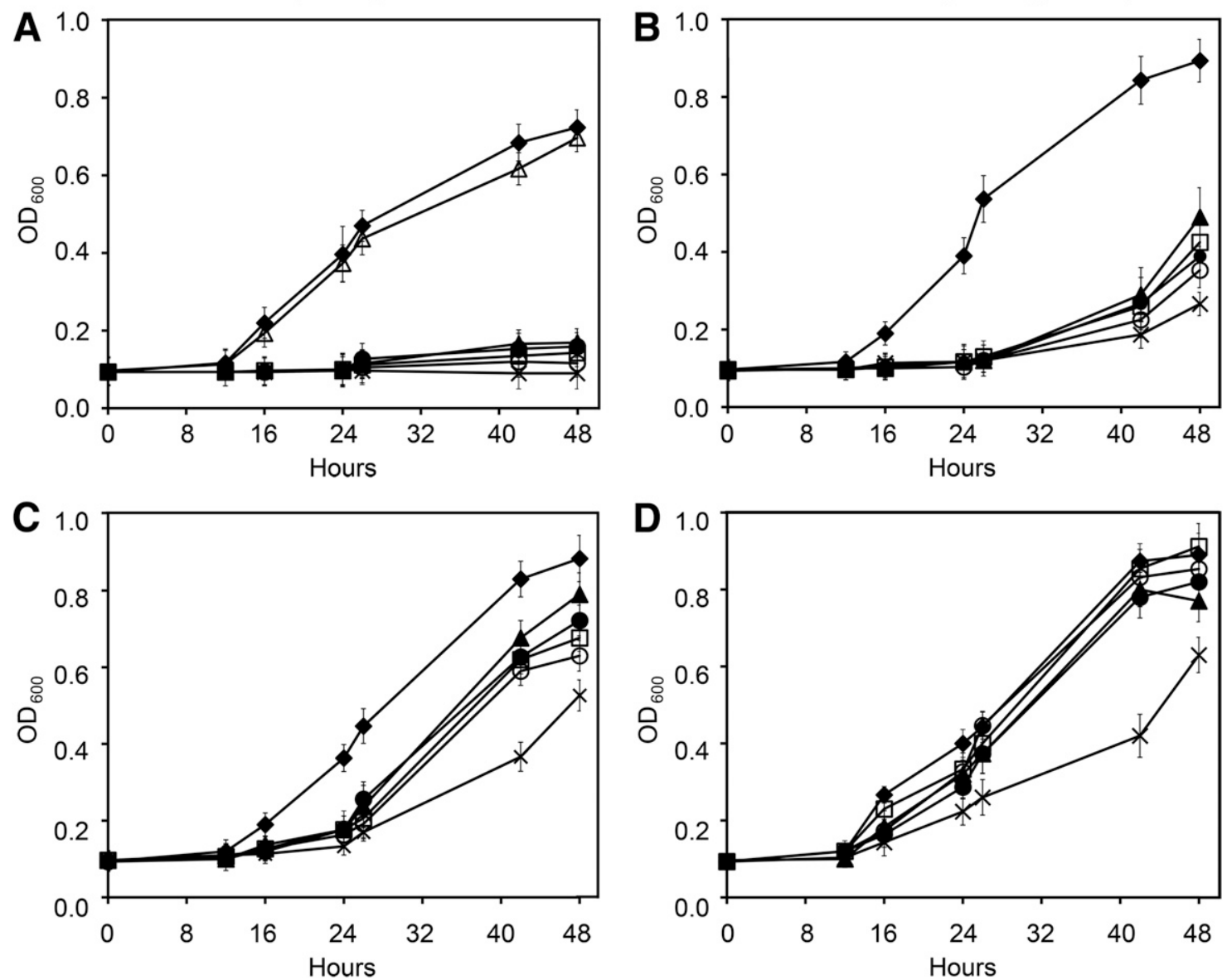

Fig. 4. Growth of Rlv3841, ModABC, and ModABC/Sul mutants at different concentrations of molybdate. Strains were grown in sulfate- and molybdenumfree acid minimal salt $\mathrm{Glc} / \mathrm{NO}_{3}{ }^{-}$supplemented with $2 \mathrm{mM} \mathrm{Na}_{2} \mathrm{SO}_{4}$ and $\mathbf{A}$, no added $\mathrm{Mo}, \mathbf{B}, 0.25 \mu \mathrm{M} \mathrm{Na}_{2} \mathrm{MoO}_{4}, \mathbf{C}, 1 \mu \mathrm{M} \mathrm{Na}_{2} \mathrm{MoO}_{4}$, and $\mathbf{D}, 2.5 \mu \mathrm{M} \mathrm{Na} 2 \mathrm{MoO}_{4}$. Wild-type Rlv3841 was compared with mutants $\operatorname{modB}$ (LMB695), modB sulB (LMB696), $\operatorname{modB}$ sulP1 (LMB706), $\operatorname{modB}$ sulP2 (LMB702), and modB sulB sulP1 sulP2 (LMB709) and complemented ModABC mutant modB[pLMB801] (LMB741). Data are from three biological samples \pm standard error of the mean. 
sulfate transport. This is apparent because in S- and Mo-free plant-growth medium, the quadruple mutant, in which one or more of these unidentified systems will still be active, reduces acetylene at the same rate as wild-type Rlv3841. However, in the presence of $10 \mathrm{mM}$ sulfate, during which this system is inhibited, $\bmod B$ mutants show a large decrease in ability to reduce acetylene. We assume this system transports sulfate, although, formally, the data shows its ability to transport molybdate is inhibited by sulfate. The multiplicity of overlapping sulfate and molybdate transporters explains why bacterial phenotypes lacking the ability to fix $\mathrm{N}$ have not been seen for transporters of these ions that are essential for $\mathrm{N}$ fixation.

\section{DISCUSSION}

The presence of multiple transport systems for uptake of sulfate and molybdate is likely to mean that the requirement for these anions within the cell is crucially important to members of genus Rhizobium. We have seen a similar scenario in the numerous transport systems not only present in the genome of

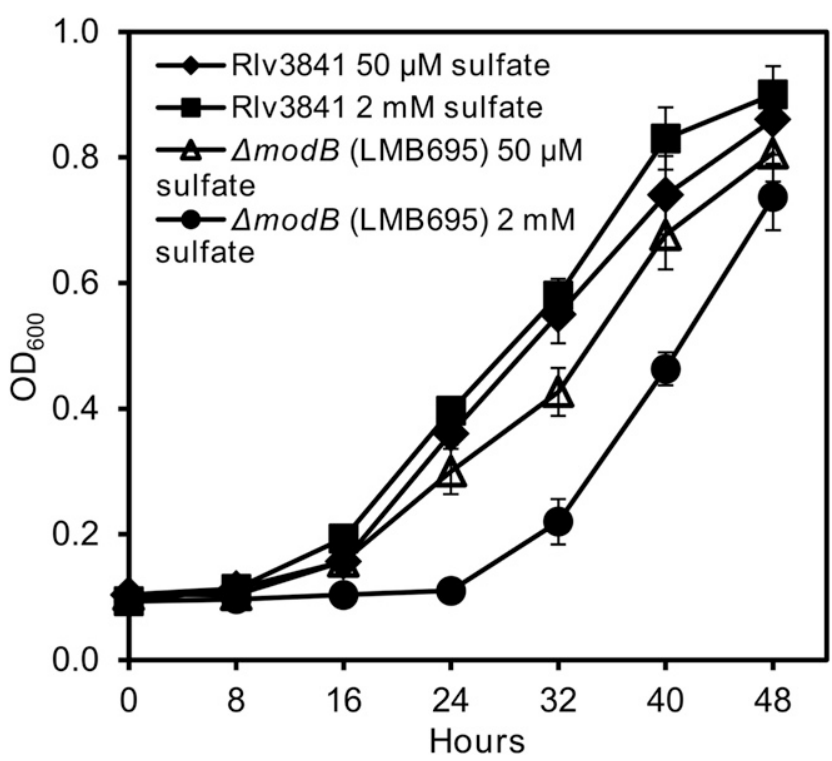

Fig. 5. Growth of Rlv3841 and a ModABC mutant in $50 \mu \mathrm{M} \mathrm{Na}_{2} \mathrm{SO}_{4}$ (low sulfate) and $2 \mathrm{mM} \mathrm{Na}_{2} \mathrm{SO}_{4}$ (high sulfate) media. Sulfate was added to sulfate- and molybdenum (Mo)-free acid minimal salt $\mathrm{Glc} / \mathrm{NO}_{3}{ }^{-}$supplemented with $0.5 \mu \mathrm{M} \mathrm{Na} \mathrm{MoO}_{4}$. Growth of wild-type Rlv3841 was compared with that of $\operatorname{modB}$ (LMB695). Data are from three biological samples \pm standard error of the mean. this organism but also activated in different environments, e.g., the rhizosphere (Ramachandran et al. 2011), and in bacteroids (Karunakaran et al. 2009). This leads to robustness, because an organism doesn't rely totally on a single method of uptake of an important substrate and also confers ability to 'fine tune' transport depending upon the environment. However, this multiplicity of transport systems means that it is difficult to get clear knock-out phenotypes and makes it hard to study even transport systems crucial to the bacteria.

Characterization of mutant strains shows that $\mathrm{ABC}$ transporter SulABCD is the main high-affinity system responsible for transport of sulfate in Rlv3841, with SulP1 and SulP2 acting as lower-affinity systems. The strong induction of expression ( $>300$-fold) of this Sul system from Rlv3841 in low-sulfate media, measured by qRT-PCR of $s u l B$, is similar to that of the Sul system encoded by SMb21130-SMb21133 in Sinorhizobium meliloti. The expression of SMb21133 (encoding the SBP) was examined with a GFP transcriptional fusion and was shown to be induced by sulfate-limitation (Mauchline et al. 2006).

Mutation of ModABC was sufficient to prevent growth on nitrate without the addition of molybdate to the growth medium, indicating that, in wild-type Rlv3841, ModABC is able to scavenge Mo from the medium (Mo is notoriously difficult to totally remove from growth media) (Fig. 4). This growth effect can be seen because nitrate reductase is a molybdoenzyme required for growth of Rhizobium species on nitrate (Ferroni et al. 2011). The long lag phase in growth of ModABC mutant at concentrations of molybdate $(0.25$ to $2.5 \mu \mathrm{M})$ (Fig. 4) can be explained by the observation that mutations in metal transporters often cause long lag phases rather than outright loss of growth in bacterial strains. This is presumably due to slow accumulation of the metal by transporters other than ModABC, enabling a critical intracellular concentration for growth to be reached after a lag. The fact that strain LMB709, the quadruple mutant (mutated in all four Sul and ModABC transport systems), has a longer lag and slower growth at $2.5 \mu \mathrm{M}$ molybdate (Fig. 4D) is consistent with SulABCD, SulP1, and SulP2 being able to carry out molybdate uptake to some extent. We did not isolate all combinations of Sul transporter mutations to determine their individual contribution to molybdate transport, as the overall effect is modest and they may all contribute to some extent. Furthermore, there must be least one additional way for molybdate to enter the cell to enable the slow growth observed in the quadruple mutant. The idea that the Sul transporters play some part in molybdate uptake in Rlv3841 is substantiated by the observation that growth of $\operatorname{modB}$ mutant (LMB695) is inhibited by a high concentration of sulfate (Fig. 5), which could be due to sulfate inhibiting molybdate uptake by one or more of the Sul transport systems. A similar situation in which

Table 2. Expression of genes involved in uptake of sulfate measured by quantitative reverse transcription-polymerase chain reaction analysis

\begin{tabular}{|c|c|c|c|c|}
\hline \multirow[b]{2}{*}{ Strain $^{y}$} & \multicolumn{4}{|c|}{ Gene expression $^{z}$} \\
\hline & $\operatorname{modB}$ & sulB & sulP1 & sulP2 \\
\hline \multicolumn{5}{|l|}{ Experiment A } \\
\hline LMB584 (sulB) & $0.61 \pm 0.21$ & $0.003 \pm 0.00$ & $* 4.78 \pm 1.48$ & $* 8.69 \pm 3.11$ \\
\hline LMB694 (sulP2) & $0.75 \pm 0.10$ & $0.980 \pm 0.42$ & $0.96 \pm 0.05$ & nd \\
\hline LMB700 (sulP1) & $0.86 \pm 0.35$ & $0.640 \pm 0.22$ & nd & $0.68 \pm 0.26$ \\
\hline LMB701 (sulP1 sulP2) & $0.84 \pm 0.31$ & $* 0.280 \pm 0.09$ & nd & nd \\
\hline \multicolumn{5}{|l|}{ Experiment B } \\
\hline Rlv3841 (wild-type) & $* 6.18 \pm 2.79$ & $* 313.290 \pm 7.18$ & $* 114.71 \pm 69.80$ & $* 3.96 \pm 2.34$ \\
\hline
\end{tabular}


molybdate can be also taken up by the sulfate transport system has been observed in both E. coli (Rosentel et al. 1995) and Bradyrhizobium japonicum (Delgado et al. 2006).

The reduction of $\mathrm{N}$ to ammonia by bacteroid nitrogenase is dependent on Mo (in the form of molybdate), making molybdate acquisition by bacteroids essential for a functional symbiosis. This is illustrated, in this work, when pea plants were grown in media with a high concentration of sulfate, and bacteroids with a mutation in $\operatorname{modB}$ reduced acetylene at only $14.3 \%$ of the wild-type rate (Table 4 ). This highlights the overlap between sulfate and molybdate transport because, in low-sulfate medium, $\operatorname{modB}$ mutants fixed $\mathrm{N}$ at wild-type rates, showing they could acquire sufficient molybdate, presumably by a system that also transports sulfate. There is also likely to be complex regulation of $\mathrm{S}$ transporters, since a partial inactivation of $\mathrm{S}$ transport in a $\operatorname{modB}$ background restored acetylene reduction to wild-type rates. This suggests mutation of one or two of the sul transporters causes a compensation by one or more remaining transporters, resulting in an increased steady state accumulation of molybdate. The effect can be very subtle, because only trace amounts of molybdate need to be obtained by bacteroids. However, the effect appears real, as it could be repeated, and once all three characterized sul transporters were mutated in a $\bmod B$ background, acetylene reduction was once again severely inhibited (Table 4). Finally, the effects on growth

Table 3. Expression of genes involved in molybdate and sulfate uptake $\mathrm{e}^{\mathrm{x}}$

\begin{tabular}{lccc}
\hline & \multicolumn{2}{c}{ Average fold change in expression } & \\
\cline { 2 - 3 } Gene & Early log phase & Late log phase & Bacteroids $^{\mathbf{z}}$ \\
\hline $\bmod A$ & $\mathrm{Nd}$ & $\mathrm{Nd}$ & $* * 2.85$ \\
$\operatorname{modB}$ & $* 3.04 \pm 1.21$ & $* 7.51 \pm 4.66$ & 1.78 \\
sulB & $1.74 \pm 1.44$ & $1.12 \pm 0.22$ & 0.25 \\
sulP1 & $0.76 \pm 0.47$ & $1.23 \pm 0.39$ & 1.80 \\
sulP2 & $0.67 \pm 0.49$ & $1.10 \pm 0.16$ & 0.83 \\
\hline
\end{tabular}

${ }^{\mathrm{x}}$ Measured by quantitative reverse transcription-polymerase chain reaction analysis analysis of Rlv3841 grown in molybdate-free and molybdate containing media and in pea bacteroids. In the microarray experiments, all media were high in sulfate and molybdenum. Bacteria were grown in sulfate and molybdenum-free acid minimal salt $\mathrm{Glc} / \mathrm{NO}_{3}{ }^{-}$supplemented with $2 \mathrm{mM} \mathrm{Na}_{2} \mathrm{SO}_{4}$ and containing either no added molybdate or $10 \mu \mathrm{M}$ $\mathrm{Na}_{2} \mathrm{MoO}_{4}$

y As compared with molybdate-containing media. Values are given \pm standard error of the mean. One asterisk $(*)$ indicates gene expression was at least twofold higher in media with no added molybdate compared with that supplemented with $10 \mu \mathrm{M} \mathrm{Na}_{2} \mathrm{MoO}_{4}$, with $P$ value $\leq 0.05$. $\mathrm{Nd}=$ not determined.

${ }^{\mathrm{z}}$ From microarray data on 21-day pea bacteroids (Karunakaran et al. 2009). Two asterisks (**) indicate expression was at least twofold higher in bacteroids than in free-living Rlv3841 (Karunakaran et al. 2009), with $P$ value $<0.05$. and acetylene reduction in the quadruple mutant $(\operatorname{modB} s u l B$ sulP1 sulP2) demonstrates that there must be yet another system (or systems) that is able to transport both molybdate and sulfate. This system cannot be capable of high-affinity molybdate uptake, because mutation of $\bmod B$ alone is capable of preventing growth on $\mathrm{NO}_{3}{ }^{-}$as a sole $\mathrm{N}$ source on Mo-free media. From these data, we conclude that molybdate transport is essential for $\mathrm{N}$ fixation in low molybdate growth conditions, particularly when sulfate is abundant.

\section{MATERIALS AND METHODS}

\section{Bacterial growth and media.}

The strains and plasmids used in this study are listed in Table 1. Rhizobium strains were grown at $28^{\circ} \mathrm{C}$ in either tryptone yeast extract (Beringer 1974) or AMS (Poole et al. 1994) with D-glucose $(10 \mathrm{mM})$ as a carbon source and $\mathrm{NH}_{4} \mathrm{Cl}(10 \mathrm{mM})$ or $\mathrm{NaNO}_{3}(10 \mathrm{mM})$ as a nitrogen source (referred to as AMS Glc/ $\mathrm{NH}_{4}{ }^{+}$and AMS Glc/ $/ \mathrm{NO}_{3}{ }^{-}$, respectively). For growth and qRT-PCR experiments, cells were grown in S- and Mo-free medium based on AMS, in which all sulfate salts have been replaced with chlorides, and phosphate buffer $(10 \mathrm{mM})$ was used instead of MOPS. When required, $\mathrm{Na}_{2} \mathrm{SO}_{4}$ and $\mathrm{Na}_{2} \mathrm{MoO}_{4}$ were added to the concentration stated. Antibiotics were used at the following concentrations $(\mu \mathrm{g} / \mathrm{ml})$ : ampicillin, 50; apramycin, 50; gentamicin, 20; kanamycin, 20; neomycin, 80; spectinomycin, 100; streptomycin, 500; and tetracycline, 5. Strains were grown at $28^{\circ} \mathrm{C}$ with shaking $(200 \mathrm{rpm})$ for liquid media. To monitor culture growth, optical density at $600 \mathrm{~nm}\left(\mathrm{OD}_{600}\right)$ measured on three independent cultures.

\section{Construction of strains with mutations in genes encoding sulfate and molybdate transporters.}

In order to produce a series of stable mutants in the sulfate and molybdate transporters, which could be combined to give strains with two, three, and four mutated transporters, genes were interrupted by insertion of an antibiotic resistance gene. In each case, the mutation of a gene in Rhizobium species was checked by PCR, with mapping primers designed to regions upand downstream of the position of antibiotic resistance insertion. Construction of the strains mutated in a single gene is initially described (Fig. 1), followed by the methods by which the mutations were combined.

To mutate sulA, primers pr1382 and pr1383 were used to PCR-amplify sulA (pRL110374) from Rlv3841 genomic DNA, as described previously (Karunakaran et al. 2009), and the 3.0-kb product was cloned into linearized vector pJET1.2/blunt (Thermo Fisher Scientific, Hemel Hempstead, U.K.), according to the manufacturer's instructions, giving plasmid pLMB670. A

Table 4. Symbiotic behavior of Rhizobium leguminosarum mod and sul mutants measured by acetylene reduction

\begin{tabular}{|c|c|c|c|c|c|}
\hline \multirow[b]{2}{*}{ Strain } & \multirow[b]{2}{*}{ Genotype } & \multicolumn{4}{|c|}{ Micromoles acetylene per plant per hour ${ }^{y}$} \\
\hline & & Mo-free S-free & Mo-free $10 \mathrm{mM} \mathrm{Na}_{2} \mathrm{SO}_{4}{ }^{\mathrm{z}}$ & $1 \mu \mathrm{M} \mathrm{Na}{ }_{2} \mathrm{MoO}_{4} 10 \mathrm{mM} \mathrm{Na}_{2} \mathrm{SO}_{4}$ & Mo-free $10 \mathrm{mM} \mathrm{Na}_{2} \mathrm{SO}_{4}{ }^{\mathrm{z}}$ \\
\hline Rlv3841 & Wild-type & $2.33 \pm 0.03 a$ & $3.69 \pm 0.59 a$ & $3.52 \pm 0.44 a$ & $4.15 \pm 0.17 \mathrm{a}$ \\
\hline LMB584 & sulB & $2.48 \pm 0.05 a$ & $3.40 \pm 0.15 \mathrm{a}$ & $3.33 \pm 0.28 \mathrm{a}$ & $3.62 \pm 0.15 \mathrm{a}$ \\
\hline LMB695 & $\bmod B$ & $2.50 \pm 0.22 \mathrm{a}$ & $0.57 \pm 0.12 b$ & $3.08 \pm 0.15 a$ & $1.69 \pm 0.23 b$ \\
\hline LMB696 & $\operatorname{modB} \operatorname{sulB}$ & $2.22 \pm 0.12 \mathrm{a}$ & $3.56 \pm 0.41 \mathrm{a}$ & $2.69 \pm 0.32 \mathrm{a}$ & $3.76 \pm 0.10 \mathrm{a}$ \\
\hline LMB699 & $\operatorname{modB}$ sulB sulP1 & $2.19 \pm 0.31 \mathrm{a}$ & $3.63 \pm 0.42 \mathrm{a}$ & $2.85 \pm 0.28 \mathrm{a}$ & $3.64 \pm 0.32 \mathrm{a}$ \\
\hline LMB697 & $\operatorname{modB}$ sulB sulP2 & $2.03 \pm 0.12 \mathrm{a}$ & $3.03 \pm 0.50 \mathrm{a}$ & $3.33 \pm 0.30 \mathrm{a}$ & $3.55 \pm 0.48 \mathrm{a}$ \\
\hline LMB707 & $\operatorname{modB}$ sulP1 sulP2 & $2.38 \pm 0.29 a$ & $3.18 \pm 0.15 \mathrm{a}$ & $2.85 \pm 0.28 \mathrm{a}$ & $3.60 \pm 0.09 \mathrm{a}$ \\
\hline LMB708 & sulB sulP1 sulP2 & $2.34 \pm 0.28 \mathrm{a}$ & $3.64 \pm 0.40 \mathrm{a}$ & $3.25 \pm 0.20 \mathrm{a}$ & $3.70 \pm 0.36 \mathrm{a}$ \\
\hline LMB709 & $\operatorname{modB}$ sulB sulP1 sulP2 & $2.01 \pm 0.29 a$ & $0.64 \pm 0.66 b$ & $2.76 \pm 0.13 \mathrm{a}$ & $2.15 \pm 0.17 b$ \\
\hline
\end{tabular}

${ }^{y}$ Data are averages of five independent plants \pm standard error of the mean. Mo $=$ molybdenum; $\mathrm{S}=$ sulfur. Letters a and $\mathrm{b}$ indicate whether acetylene reduction rates were significantly different from wild-type grown under the same conditions, with $P$ value $<0.01$.

$\mathrm{z}$ These two experiments are independent repeats. Uninoculated control points were not nodulated and did not reduce acetylene. 
282-bp deletion was introduced into sulA by inverse PCR with primers pr1384 and pr1385, using pLMB670 as template. This PCR product was cut with EcoRI and was religated to give plasmid pLMB680. The kanamycin-resistance cassette from

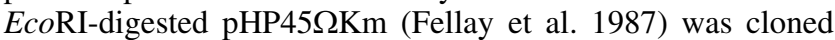
into the unique EcoRI site of pLMB680, producing pLMB681. The XbaI/XhoI fragment from pLMB681 was cloned into pJQ200SK to create pLMB682. Plasmid pLMB682 was conjugated into strain Rlv3841, and a kanamycin-resistant $\Delta$ sulA mutant (LMB595) was isolated by selecting for recombination, using the sac mutagenesis strategy, as previously described (Kumar et al. 2005). The insertion was mapped by PCR, using primers pr1386 and pr1387 together with pOTfarforward.

To mutate $s u l B$, primers pr1388 and pr1389 were used to PCRamplify the $s u l B$ (pRL110373) region from Rlv3841 genomic DNA. The 2.8-kb product was cloned into pJET1.2/blunt, giving plasmid pLMB671. The spectinomycin-resistance cassette from

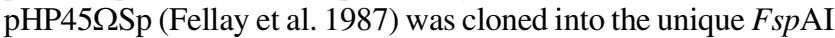
site of pLMB671, which is within the $s u l B$ gene, to produce pLMB674. The $B g l I I$ fragment from pLMB674 was cloned into BamHI-digested pJQ200SK to create pLMB675. Plasmid pLMB675 was conjugated into strain Rlv3841, to produce a spectinomycinresistant sulB mutant (LMB584), as previously described (Kumar et al. 2005). This insertion was mapped by PCR, using primers pr1390 and pr1391 together with pOTfarforward.

To mutate $\bmod B$, primers pr1471 and pr1472 were used to PCR-amplify $\operatorname{modB}$ (RL4686) from Rlv3841 genomic DNA, and the 2.7-kb PCR product was cloned into pJET1.2/blunt, giving plasmid pLMB754. The tetracycline-resistance cassette from $\mathrm{pHP} 45 \Omega$ Tet (Fellay et al. 1987) was cloned by digesting pLMB754 with EcoRI (there are two sites approximately $70 \mathrm{bp}$ apart that lie within $\operatorname{modB}$ ) and ligating, to produce pLMB755. The BglII fragment from pLMB755 was cloned into BamHIdigested pJQ200SK to create pLMB756. Plasmid pLMB756 was conjugated into strain Rlv3841 and LMB584 (sulB) to produce tetracycline-resistant $\operatorname{modB}$ mutants LMB695 $(\bmod B)$ and double mutant LMB696 $(\operatorname{modB} s u l B)$, as previously described (Kumar et al. 2005). This insertion was mapped by PCR, using primers pr1473 and pr1474 together with pOTfarforward.

To mutate sulP1, primers pr1463 and pr1464 were used to PCR-amplify sulPl (RL2866) from Rlv3841 genomic DNA, and the $3.7-\mathrm{kb}$ product was cloned into pJET1.2/blunt, giving

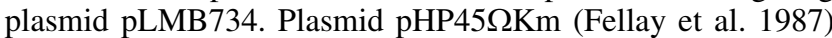
was digested with $E c o$ RI, and the ends were filled to clone the kanamycin-resistance cassette into the unique SmaI site (within sulP1) of pLMB734 to produce pLMB784. The XhoI fragment from pLMB784 was cloned into XhoI-digested pJQ200SK to form pLMB785. Plasmid pLMB785 was conjugated into strains Rlv3841, LMB584 (sulB), and LMB696 ( $\operatorname{modB} s u l B)$ to produce kanamycin-resistant sulP1 mutants LMB700 (sulPl), double mutant LMB705 (sulB sulP1), and triple mutant LMB699 ( $\operatorname{modB}$ sulB sulP1), respectively, as previously described (Kumar et al. 2005). This insertion was mapped by PCR, using primers pr1465 and pr1466 together with pOTfarforward.

To mutate sulP2, primers pr1467 and pr1468 were used to PCR-amplify sulP2 (RL2944) from Rlv3841 genomic DNA, and the $3.5-\mathrm{kb}$ product was cloned into pJET1.2/blunt, giving plasmid pLMB751. The 0.9-kb XmnI/SmaI fragment encoding apramycin resistance from pIJ773 (Gust et al. 2003) was cloned into the unique AfeI site of pLMB751, which is within the sulP2 gene, to produce $\mathrm{pLMB} 752$. The NotI fragment from $\mathrm{pLMB} 752$ was cloned into pJQ200Sp to form pLMB778. Plasmid pLMB778 was conjugated into strain Rlv3841 to produce apramycinresistant sulP2 mutant LMB694, as previously described (Kumar et al. 2005). This insertion was mapped by PCR, using primers pr1504 and pr1505 together with primers Apr-for and Apr-rev.
Following generation of strains with a single mutation, these mutations were then combined to construct double, triple, and quadruple mutants, as described below. To introduce the apramycin resistance-marked sulP2::Apr mutation into strains to make further mutants, the general transducing phage RL38 was used to lyse strain LMB694 (sulP2::Apr). Using transduction (Buchanan-Wollaston, 1979) of apramycin resistance to LMB695 $(\operatorname{modB})$, strain LMB702 ( $\operatorname{modB}$ sulP2) was generated. In a similar way, transduction of double mutant LMB696 $(\operatorname{modB} s u l B)$ was used to generate LMB697 ( $\operatorname{modB}$ sulB sulP2) and transduction of triple mutant LMB699 ( $\operatorname{modB}$ sulB sulP1), to generate LMB709 ( $\operatorname{modB}$ sulB sulP1 sulP2) (Table 1).

In order to introduce the spectinomycin resistance-marked

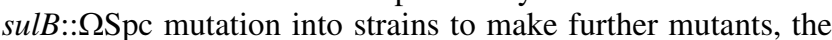
general transducing phage RL38 was used to lyse strain LMB584

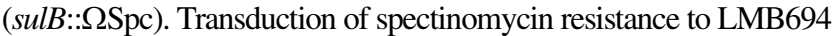
(sulP2) was used to generate strain LMB698 (sulB sulP2). In a similar way, transduction of LMB700 (sulP1) was used to generate LMB705 (sulB sulPl) and transduction of double mutant LMB701 (sulP1 sulP2) was used to generate triple mutant LMB708 (sulB sulP1 sulP2).

To introduce the tetracycline-marked $\operatorname{modB}: \Omega$ Tet mutation into strains, the general transducing phage RL38 was used to lyse strain LMB695 (modB::STet). Selecting for tetracyclineresistant transductants of LMB700 (sulP2) generated double mutant LMB706 ( $\operatorname{modB}$ sulP1), and transduction of LMB701 (sulP1 sulP2) generated triple mutant LMB707 ( $\operatorname{modB}$ sulP1 sulP2) (Table 1).

\section{Complementation of ModABC and Sul mutants.}

To complement the ModABC mutant, primers pr1605 and pr1606 were used to amplify the whole $\bmod A B C$ operon from Rlv3841 (Fig. 1). The 3.5-kb PCR product was digested with

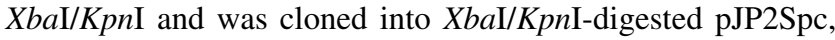
resulting in plasmid pLMB801. Plasmid pLMB801was conjugated into LMB695 $(\operatorname{modB})$ strain using pRK2013 as helper plasmid. Using selection for spectinomycin resistance, complemented strain LMB741 was isolated according to the method previously described (Figurski and Helinski 1979).

To complement Sul mutants, primers pr1459/pr1460 were used to amplify sulABCD genes from Rlv3841 (Fig. 1). The 4.2-kb PCR product was digested with $X b a \mathrm{I}$ and was then cloned into XbaI-digested pRK415-1 (a broad-host range plasmid, stably maintained in Rhizobium spp.), resulting in plasmid pLMB731. Plasmid pLMB731 was conjugated into LMB584 (sulB) to make complemented strain LMB631 and was conjugated into LMB595 $(\Delta$ sulA) to make complemented strain LMB633 by selection for tetracycline resistance.

\section{RNA isolation and qRT-PCR analysis.}

Transcripts of mod and sul genes were analyzed using qRTPCR. RNA was prepared from Rlv3841 and its mutant derivatives by extracting RNA from three independent cultures. Bacterial cells were grown aerobically in S- and Mo-free AMS Glc/NO ${ }_{3}^{-}$ or AMS Glc $/ \mathrm{NH}_{4}{ }^{+}$, supplemented, if required, with either sulfate $\left(100 \mu \mathrm{M}\right.$ or $\left.2 \mathrm{mM} \mathrm{Na}_{2} \mathrm{SO}_{4}\right)$, molybdate $(1 \mu \mathrm{M}$ or $10 \mu \mathrm{M}$ $\mathrm{Na}_{2} \mathrm{MoO}_{4}$ ), or both. Cultures were grown overnight or were harvested at early $\left(\mathrm{OD}_{600}=0.3\right)$ or late $\left(\mathrm{OD}_{600}=0.7\right) \log$ phase.

Bacterial cultures $(12 \mathrm{ml})$ were added directly to $24 \mathrm{ml} \mathrm{pf}$ RNAlater (Ambion, Hemel Hempstead, U.K.) and were harvested by centrifugation at $4^{\circ} \mathrm{C}$ (Karunakaran et al. 2009). RNA was treated twice with DNase (TURBO DNA-free; Ambion). cDNA was synthesized using SuperScript II reverse transcriptase and random hexamers (Invitrogen, Hemel Hempstead, U.K.). Quantification of cDNA was carried out using the SensiMix SYBR No-ROX kit (Bioline, London), and real-time amplification of the PCR products was performed on samples in 
triplicate, using the CFX real-time PCR system (Bio-Rad, Hemel Hempstead, U.K.), as described by Mulley et al. (2011). Primers for $\operatorname{modB}, \operatorname{sulB}$, sulP1, sulP2, and gyrb1 qRT-PCR are detailed in Supplementary Table S1. PCR consisted of an initial incubation step for $3 \mathrm{~min}$ at $95^{\circ} \mathrm{C}$, followed by 35 cycles for $5 \mathrm{~s}$ at $95^{\circ} \mathrm{C}, 10 \mathrm{~s}$ at $62^{\circ} \mathrm{C}$, and $5 \mathrm{~s}$ at $72^{\circ} \mathrm{C}$. Housekeeping gene gyrbl (RL0012) was used as a calibrator gene, and results were analyzed as previously described (Prell et al. 2009). Statistical analysis of data sets was performed using REST (Pfaffl et al. 2002).

\section{Plant experiments and acetylene reduction.}

Seeds of Pisum sativum cv. Avola were surface-sterilized, were placed in 1-liter pots containing sterile vermiculite, and were watered with sterile $\mathrm{S}$-, Mo-, and $\mathrm{N}$-free rooting solution $\left(1 \mathrm{mM} \mathrm{CaCl} 2 \cdot 2 \mathrm{H}_{2} \mathrm{O}, 100 \mu \mathrm{M} \mathrm{KCl}, 800 \mu \mathrm{M} \mathrm{MgCl} 2 \cdot 7 \mathrm{H}_{2} \mathrm{O}\right.$, $10 \mu \mathrm{M}$ Fe EDTA, $35 \mu \mathrm{M} \mathrm{H}_{3} \mathrm{BO}_{3}, 9 \mu \mathrm{M} \mathrm{MnCl}_{2} \cdot 4 \mathrm{H}_{2} \mathrm{O}, 0.8 \mu \mathrm{M}$ $\mathrm{ZnCl}_{2}, 0.3 \mu \mathrm{M} \mathrm{CuCl}_{2} \cdot 5 \mathrm{H}_{2} \mathrm{O}, 7.2 \mathrm{mM} \mathrm{KH}_{2} \mathrm{PO}_{4}$, and $7.2 \mathrm{mM}$ $\mathrm{Na}_{2} \mathrm{HPO}_{4}$ ). When required, $10 \mathrm{mM} \mathrm{Na} \mathrm{SO}_{4}$ and $1 \mu \mathrm{m} \mathrm{Na} \mathrm{NoO}_{4}$ were added to the rooting solution. Inoculated plants were incubated in a controlled-environment chamber and were harvested at 3 to 4 weeks. Acetylene reduction was determined for five independent plants in each case, as previously described (Allaway et al. 2000).

\section{ACKNOWLEDGMENTS}

This study was funded by a grant to G. Cheng from the China Scholarship Council and the Fundamental Research Funds for the Central Universities, South-Central University for Nationalities (CZZ12005) and by the Biotechnology and Biological Sciences Research Council U.K. (BB/J007749/1).

\section{LITERATURE CITED}

Allaway, D., Lodwig, E. M., Crompton, L. A., Wood, M., Parsons, R., Wheeler, T. R., and Poole, P. S. 2000. Identification of alanine dehydrogenase and its role in mixed secretion of ammonium and alanine by pea bacteroids. Mol. Microbiol. 36:508-515.

Anderson, L. A., McNairn, E., Lubke, T., Pau, R. N., and Boxer, D. H. 2000. ModE-dependent molybdate regulation of the molybdenum cofactor operon moa in Escherichia coli. J. Bacteriol. 182:7035-7043.

Beringer, J. E. 1974. R factor transfer in Rhizobium leguminosarum. J. Gen. Microbiol. 84:188-198.

Buchanan-Wollaston, V. 1979. Generalized transduction in Rhizobium leguminosarum. J. Gen. Microbiol. 112:135-142.

Delgado, M. J., Tresierra-Ayala, A., Talbi, C., and Bedmar, E. J. 2006. Functional characterization of the Bradyrhizobium japonicum modA and modB genes involved in molybdenum transport. Microbiology 152:199207.

Fellay, R., Frey, J., and Krisch, H. 1987. Interposon mutagenesis of soil and water bacteria: A family of DNA fragments designed for in vitro insertional mutagenesis of gram-negative bacteria. Gene 52:147-154.

Ferroni, F. M., Rivas, M. G., Rizzi, A. C., Lucca, M. E., Perotti, N. I., and Brondino, C. D. 2011. Nitrate reduction associated with respiration in Sinorhizobium meliloti 2011 is performed by a membrane-bound molybdoenzyme. Biometals 24:891-902.

Figurski, D. H., and Helinski, D. R. 1979. Replication of an origincontaining derivative of plasmid RK2 dependent on a plasmid function provided in trans. Proc. Natl. Acad. Sci. U.S.A. 76:1648-1652.

Grunden, A. M., and Shanmugam, K. T. 1997. Molybdate transport and regulation in bacteria. Arch. Microbiol. 168:345-354.

Gust, B., Challis, G. L., Fowler, K., Kieser, T., and Chater, K. F. 2003. PCRtargeted Streptomyces gene replacement identifies a protein domain needed for biosynthesis of the sesquiterpene soil odor geosmin. Proc. Natl. Acad. Sci. U.S.A. 100:1541-1546.

Hille, R. 2002. Molybdenum and tungsten in biology. Trends Biochem. Sci. 27:360-367.

Hryniewicz, M., Sirko, A., Pałucha, A., Böck, A., and Hulanicka, D. 1990. Sulfate and thiosulfate transport in Escherichia coli K-12: Identification of a gene encoding a novel protein involved in thiosulfate binding. J. Bacteriol. 172:3358-3366.

Hummerjohann, J., Küttel, E., Quadroni, M., Ragaller, J., Leisinger, T., and Kertesz, M. A. 1998. Regulation of the sulfate starvation response in
Pseudomonas aeruginosa: Role of cysteine biosynthetic intermediates. Microbiology 144:1375-1386.

Johnston, A. W. B., and Beringer, J. E. 1975. Identification of the Rhizobium strains in pea root nodules using genetic markers. J. Gen. Microbiol. 87:343-350.

Karunakaran, R., Ramachandran, V. K., Seaman, J. C., East, A. K., Mouhsine, B., Mauchline, T. H., Prell, J., Skeffington, A., and Poole, P. S. 2009. Transcriptomic analysis of Rhizobium leguminosarum biovar viciae in symbiosis with host plants Pisum sativum and Vicia cracca. J. Bacteriol. 191:4002-4014.

Keen, N. T., Tamaki, S., Kobayashi, D., and Trollinger, D. 1988. Improved broad-host-range plasmids for DNA cloning in gram-negative bacteria Gene 70:191-197.

Kertesz, M. A. 2001. Bacterial transporters for sulfate and organosulfur compounds. Res. Microbiol. 152:279-290.

Kertesz, M. A., and Mirleau, P. 2004. The role of soil microbes in plant sulphur nutrition. J. Exp. Bot. 55:1939-1945.

Kredich, N. M. 1996. Biosynthesis of cysteine. Pages 514-527 in: Escherichia coli and Salmonella: Cellular and Molecular Biology. F. C. Neidhardt, ed. ASM Press, Washington, D. C.

Kumar, S., Bourdès, A., and Poole, P. 2005. De novo alanine synthesis by bacteroids of Mesorhizobium loti is not required for nitrogen transfer in the determinate nodules of Lotus corniculatus. J. Bacteriol. 187:54935495.

Mauchline, T. H., Fowler, J. E., East, A. K., Sartor, A. L., Zaheer, R., Hosie, A. H. F., Poole, P. S., and Finan, T. M. 2006. Mapping the Sinorhizobium meliloti 1021 solute-binding protein-dependent transportome. Proc. Natl. Acad. Sci. U.S.A. 103:17933-17938.

Mulley, G., White, J. P., Karunakaran, R., Prell, J., Bourdès, A., Bunnewell, S., Hill, L., and Poole, P. S. 2011. Mutation of GOGAT prevents pea bacteroid formation and $\mathrm{N}_{2}$ fixation by globally downregulating transport of organic nitrogen sources. Mol. Microbiol. 80:149-167.

Pfaffl, M. W., Horgan, G. W., and Dempfle, L. 2002. Relative expression software tool (REST) for group-wise comparison and statistical analysis of relative expression results in real-time PCR. Nucleic Acids Res. 30:e36.

Piłsyk, S., and Paszewski, A. 2009. Sulfate permeasesphylogenetic diversity of sulfate transport. Acta Biochim. Pol. 56:375-384.

Poole, P. S., Schofield, N. A., Reid, C. J., Drew, E. M., and Walshaw, D. L. 1994. Identification of chromosomal genes located downstream of $d c t D$ that affect the requirement for calcium and the lipopolysaccharide layer of Rhizobium leguminosarum. Microbiology 140:2797-2809.

Prell, J., Bourdès, A., Karunakaran, R., Lopez-Gomez, M., and Poole, P. 2009. Pathway of $\gamma$-aminobutyrate metabolism in Rhizobium leguminosarum 3841 and its role in symbiosis. J. Bacteriol. 191:2177-2186.

Quadroni, M., James, P., Dainese-Hatt, P., and Kertesz, M. A. 1999. Proteome mapping, mass spectrometric sequencing and reverse transcriptionPCR for characterization of the sulfate starvation-induced response in Pseudomonas aeruginosa PAO1. Eur. J. Biochem. 266:986-996.

Quandt, J., and Hynes, M. F. 1993. Versatile suicide vectors which allow direct selection for gene replacement in gram-negative bacteria. Gene 127:15-21.

Ramachandran, V. K., East, A. K., Karunakaran, R., Downie, J. A., and Poole, P. S. 2011. Adaptation of Rhizobium leguminosarum to pea alfalfa and sugar beet rhizospheres investigated by comparative transcriptomics. Genome Biol. 12:R106.

Rosentel, J. K., Healy, F., Maupin-Furlow, J. A., Lee, J. H., and Shanmugam, K. T. 1995. Molybdate and regulation of mod (molybdate transport), fdhF, and hyc (formate hydrogenlyase) operons in Escherichia coli. J. Bacteriol. 177:4857-4864.

Saier, M. H., Jr., Tran, C. V., and Barabote, R. D. 2006. TCDB: The transporter classification database for membrane transport protein analyses and information. Nucleic Acids Res. 34:D181-D186.

Scheffel, F., Demmer, U., Warkentin, E., Hülsmann, A., Schneider, E., and Ermler, U. 2005. Structure of the ATPase subunit CysA of the putative sulfate ATP-binding cassette (ABC) transporter from Alicyclobacillus acidocaldarius. FEBS Lett. 579:2953-2958.

Sirko, A., Hryniewicz, M., Hulanicka, D., and Böck, A. 1990. Sulfate and thiosulfate transport in Escherichia coli K-12: Nucleotide sequence and expression of the cysTWAM gene cluster. J. Bacteriol. 172:33513357

Sirko, A., Zatyka, M., Sadowy, E., and Hulanicka, D. 1995. Sulfate and thiosulfate transport in Escherichia coli $\mathrm{K}-12$ : Evidence for a functional overlapping of sulfate- and thiosulfate-binding proteins. J. Bacteriol. 177:4134-4136.

Smith, K. S., Balistrieri, L. S., Smith, S. M., and Severson, R. C. 1997:Pages 23-46 in: Distribution and mobility of molybdenum in the terrestria environment in: Molybdenum in Agriculture. U. Gupta, ed. Cambridge University Press, Cambridge. 
Terpolilli, J. J., Hood, G. A., and Poole, P. S. 2012. What determines the efficiency of $\mathrm{N}_{2}$-fixing Rhizobium-legume symbioses? Adv. Microb. Physiol. 60:325-389.

Tralau, T., Vuilleumier, S., Thibault, C., Campbell, B. J., Hart, C. A., and Kertesz, M. A. 2007. Transcriptomic analysis of the sulfate starvation response of Pseudomonas aeruginosa. J. Bacteriol. 189:6743-6750.

van der Ploeg, J. R., Weiss, M. A., Saller, E., Nashimoto, H., Saito, N., Kertesz, M. A., and Leisinger, T. 1996. Identification of sulfate starvation-regulated genes in Escherichia coli: A gene cluster involved in the utilization of taurine as a sulfur source. J. Bacteriol. 178:54385446.
Young, J. P. W., Crossman, L. C., Johnston, A. W. B., Thomson, N. R., Ghazoui, Z. F., Hull, K. H., Wexler, M., Curson, A. R. J., Todd, J. D., Poole, P. S., Mauchline, T. H., East, A. K., Quail, M. A., Churcher, C., Arrowsmith, C., Cherevach, I., Chillingworth, T., Clarke, K., Cronin, A., Davis, P., Fraser, A Hance, Z., Hauser, H., Jagels, K., Moule, S., Mungall, K., Norbertczak, H. Rabbinowitsch, E., Sanders, M., Simmonds, M., Whitehead, S., and Parkhill, J. 2006. The genome of Rhizobium leguminosarum has recognizable core and accessory components. Genome Biol. 7:R34.

Zahalak, M., Pratte, B., Werth, K. J., and Thiel, T. 2004. Molybdate transport and its effect on nitrogen utilization in the cyanobacterium Anabaena variabilis ATCC 29413. Mol. Microbiol. 51:539-549. 